\title{
Christ, Reality, and Freedom: Trinitarian Metaphysics as a Theology of Culture ${ }^{1}$
}

\section{Michael Brain, Wycliffe College}

\begin{abstract}
This essay explores the possibility of a narrative theology of culture by drawing on the trinitarian metaphysics of Robert W. Jenson. Postliberal or narrative theologies have often been said to hinder the intercultural translation of the gospel by promoting the cultural forms of Western Christianity as the ideal, but I argue here that Jenson's theology (enlisting some distinctively postliberal themes) creates a critical distance between the church and Christian civilization, while also enabling the free creation and expression of diverse cultural expressions of the gospel. The first section of the paper is a critical project, using a trinitarian metaphysics to rule out any reduction of Christian culture to its Western expressions. Since the community of the Trinity is the one cultural form to which God's people strive, and because the church's full participation in this community is eschatological, Christian cultural expression cannot be reduced to one particular cultural form. This creates distance between the church and the world, preventing a strict identification of Christianity with Western culture. The second part of the paper then offers a constructive project, demonstrating how a trinitarian understanding of creaturely freedom enables the development of human culture. By grounding creation's freedom in the freedom of the triune persons, a trinitarian metaphysics enables the free and loving development of creation in an infinite number of ways. In doing so, Jenson's metaphysics does not compromise the diversity of human cultures, but instead allows human cultures to flourish in their endless variety.
\end{abstract}

Keywords: Narrative; Culture; Jenson; Christendom; Postliberalism

s the Western church continues its long transition into the post-Christendom future, the church in
North America and Europe must engage deeply with the question of how it should react to its new
cultural situation. Christendom does not appear to have completely ended just yet, and there certainly are those who would retrieve it by pulling every political lever that is available. They fight desperately to salvage what remains, but there is little doubt that the current trajectory will continue in the foreseeable future. In the midst of Christendom's sputtering death, the church has the new task of rethinking the relation of Christianity and culture. Negotiating the divorce terms in this bitter separation is painful and fraught with difficulty, but is a necessary task for Christians today.

It has been one of the chief goals of late twentieth and early twenty-first century theology to explore new ways of relating the gospel to culture. One theological paradigm in the second half of the twentieth century that has garnered attention is the theology of postliberalism. Often nicknamed "narrative theology," this paradigm - represented by theologians and scholars like Hans Frei and George Lindbeck - proceeds

1. Paper presented on November 1st, 2019, for the Colloquium "Christian Theology After Christendom." Organized by McGill University's School of Religious Studies and University of Toronto's Emmanuel College in honour of the work of Douglas John Hall. I am indebted to the presenters and attendees of the conference for their thoughtful comments and feedback on the original paper. 
from a non-foundationalist, grammatical-logical understanding of Christian faith. ${ }^{2}$ Christianity, according to postliberalism, is not something argued for on the basis of apologetic arguments - either of a conservative or progressive variety. Christianity is rather a realm of thinking with its own internal logical structure. The Christian faith interacts with other forms of human rationality by operating with its own coherent system of signs and logic, constituted for postliberals by the narrative picture of reality set forth in Scripture, interpreted through the visible life of the Christian community. Postliberals are inclined to say that in the contemporary age, when Christians enter into dialogue with those of other belief systems, Christians are not to seek to win converts to their position by appeal to general grounds of rationality, either in the language of evidentialist apologetics or a Neo-Protestant appeal to a common religious experience. Rather, Christians proclaim the specific internal logic of the gospel, contained in the Scriptures, and allow the scriptural witness to draw would-be disciples into its own thought world. ${ }^{3}$

But opponents of postliberal theology see a glaring problem. They perceive fragments of a Christendom mindset below the surface. Charitable readings claim that by limiting gospel proclamation to the linguistic and logical structures of the Scriptures, postliberalism problematizes the translation of the message to the hearer's self-understanding. James Kay argues, for example, that if proclamation is limited to the thought forms of the Old and New Testaments, the only way of preaching the gospel would be to aim the message at the heads of the hearers without considering their cultural and existential situations - which would hardly be an effective approach. ${ }^{4}$ More critical readings claim that in doing so, postliberalism is inherently colonial. David Congdon has asserted that if the language of proclamation is limited to the scriptural text, then the text can only ever be an intrusion upon the cultures into which the gospel moves. Cultures alien to the world of the Scriptures are expected to conform their thinking to the foreign world of the Bible. ${ }^{5}$ But in reality, they are more often expected to conform themselves to a Western interpretation of the text. On this reading, postliberalism is not merely an ineffective approach to mission in a postChristendom context, but a subtle reassertion of Western Christendom's dominance over non-Western modes of thinking. If this evaluation is in fact true, postliberalism contains the potential to harm the witness of the church and the cultures into which the gospel moves.

While these are important questions, my position is that this reading of postliberalism does not succeed. Certain varieties of narrative theology may in fact avoid these conclusions by containing the seeds of Western Christianity's own self-critique. It possesses the tools for assessing the value of Christian culture

2. For a classic exposition of postliberal theology, see George Lindbeck, The Nature of Doctrine: Religion and Theology in a Postliberal Age, ed. James Joseph Buckley (Grand Rapids: W. B. Eerdmans, 2003).

3. Postliberalism does not entirely eschew apologetic arguments or the use of philosophy for the purpose of conversing with other belief systems. Frei and Lindbeck were not afraid of interacting with the philosophers when they found it helpful. Key to their thought is an ad hoc approach to philosophical questioning. They were open to dialogue along these lines, but resisted the temptation to turn such apologetics or philosophical arguments into fixed systems imposed on theology. See Hans W. Frei, Types of Christian Theology, ed. George Hunsinger and William C. Placher (New Haven: Yale University Press, 1992), 70-91.

4. James F. Kay, Christus Praesens: A Reconsideration of Rudolf Bultmann's Christology (Grand Rapids: Eerdmans, 1994), $140-42$.

5. For an example of how this debate has often transpired, see the exchange of articles between Congdon and Walter Moberly in the Journal of Theological Interpretation. R. W. L. Moberly, "Theological Interpretation, Presuppositions, and the Role of the Church: Bultmann and Augustine Revisitied," Journal of Theological Interpretation 6, no. 1 (Spring 2012): 1-22; David W. Congdon, "Kerygma and Community: A Response to R. W. L. Moberly's Revisiting of Bultmann," Journal of Theological Interpretation 8, no. 1 (Spring 2014): 1-21; R. W. L. Moberly, "Bible and Church, Bultmann and Augustine: A Response to David Congdon," Journal of Theological Interpretation 9, no. 1 (Spring 2015): 39-48; David W. Congdon, "The Nature of the Church in Theological Interpretation: Culture, Volk, and Mission," Journal of Theological Interpretation 11, no. 1 (Spr 2017): 101-117; R. W. L. Moberly, "The Significance of the Church for Theological Interpretation: A Response to David Congdon, ”Journal of Theological Interpretation 12, no. 2 (Fall 2018): 274-286. 
without abandoning the possibility of a rigorous critique. The story of the Scriptures can authentically become the story of another group of people, temporally and culturally different from its own, without compromising the integrity of the receiving culture. To demonstrate how this might work, this essay draws on someone not affiliated directly with postliberalism, but whose thinking is worthwhile for the problem stated. Here I propose that the trinitarian metaphysics of Robert Jenson provides just the needed resources to show how postliberal ideas are plausible as a theology of culture. ${ }^{6}$ Jenson's trinitarian metaphysics functions as a narrative theology of culture, extending the particularity of Jesus' historic personal identity to every human reality. In doing so, Jenson maintains the particularity of Jesus Christ, guards against identifications of Christianity with Western culture, and enables the free expression of the Christian faith in a variety of different cultural settings. Following a brief account of his trinitarian metaphysics, the paper demonstrates how Jenson prevents a reduction of Christianity to any one cultural expression by relating the church's culture primarily to the culture of the triune God, in the mutual relations of Father, Son, and Holy Spirit. Doing so grants breathing space between the church and its eschatological fulfillment, and so between the church and Christendom, enabling us to subject certain features of Christendom to criticism. The paper then suggests that Jenson's theology contains potential for a theology of culture, as the gospel moves into each culture as a liberating Word of promise, enabling human beings to shape their own cultures towards the ultimate goal of communion with the triune God. This allows the church to embody the gospel in various cultural expressions, resulting in forms of life that are both culturally specific and faithful to the historic continuity of the church as Christ's one body.

\section{Jenson's Trinitarian Metaphysics}

Lutheran theology experienced many changes between the nineteenth and twentieth centuries. Twentieth century Lutherans worked to deconstruct the paradigm of Ritschlian theology, which had become the dominant expression of European Protestant liberalism. Named after Albrecht Ritschl and continued by Ritschl's students (Wilhelm Herrmann, Ernst Troeltsch, Adolf von Harnack), the Ritschlians created a predominantly modern form of Lutheran theology that read Luther through the lens of Kant. ${ }^{7}$ This theology was intensely anti-metaphysical and supported a fact-value distinction, as well as a dualism between the phenomena (the world as it appears to us) and the noumena (the world in itself). They viewed this Kantian, anti-metaphysical theology as the culmination of Luther's basic insight that God is to be seen primarily through the cross of Christ. As a result, theology should have no part in abstract metaphysical speculations, such as was common in medieval scholasticism. ${ }^{8}$ The only focus of Christian theology could be God for us in the person of Jesus Christ.

Despite their formal Christocentrism, however, the Ritschlians had a relatively flat vision of Jesus Christ, as a result of their historicized account of his person. Jesus of Nazareth was, for the Ritschlians, the high point of God's revelatory encounter with humanity, but his significance was reduced to the way he re-

6. Jenson himself did not claim to be a postliberal theologian, but the ideas he holds in common with them may illuminate our way. He was notoriously difficult to confine in any one category, though the similarities between his project and that of postliberalism have been correctly noted. The difference between them would consist in the overall metaphysical character of Jenson's thought. Whereas Frei and Lindbeck were more metaphysically eclectic, Jenson's project has been characterized as a systematic implementation of a handful of metaphysical principles. See Chris E. W. Green, The End Is Music: A Companion to Robert W. Jenson's Theology (Eugene: Cascade, 2018), 4-5.

7. Albrecht Ritschl, The Christian Doctrine of Justification and Reconciliation: The Positive Development of the Doctrine, ed. Alexander Beith Macaulay and H. R. Mackintosh (Edinburgh: T. \& T. Clark, 1900), 205.

8. Albrecht Ritschl, "Theology and Metaphysics," in Three Essays: Theology and Metaphysics, "Prolegomena" to the History of Pietism, Instruction in the Christian Religion (Philadelphia: Fortress, 1972), 154-55. 
vealed the character of God. Since all metaphysical explanations had to be excluded, they considered Chalcedonian doctrine of the two natures to be irrelevant speculation into God's essence. The deity of Christ became less an ontological description of Jesus and his relationship to God, and more of a functional description of the quality and nature of Jesus' human existence. For the Ritschlians, Jesus can be labelled divine because his human existence was of such quality in revealing God that the repetition of his message could bring the message of forgiveness to effect in succeeding generations. Their historicized Christology reduced Jesus' significance to the power of his human personality, rather than his agency as God. ${ }^{9}$ Although the Ritschlians saw their own project as the apex of Luther's theological insights, unlike Luther, their own historicized account of Jesus Christ was relatively lacking in content. Not even the history of Jesus had any weight on theology. It was rather what Jesus revealed about God that made him important for human redemption.

The dialectical theologies of Karl Barth, Rudolf Bultmann, and their associates subjected the Ritschlian liberal paradigm to heavy scrutiny. Like the Ritschlians, they were convinced that Christian theology had to be a contemplation of God's concrete revelation in Jesus Christ, which meant limiting metaphysical speculation into the being of God apart from Christ. But unlike the Ritschlians, they perceived the Ritschlians' historicized Christology as deifying the bourgeois German culture of their day, culminating in the theological legitimization of Germany's actions in WWI. Presuming to be a revisionary theology, liberal Protestantism was simply another manifestation of European dominance, an uncritical adoption of the values of European culture. So far as the dialectical theologians were concerned, Christocentric theology meant turning a critical lens towards nineteenth century Protestantism and the European cultural Christianity it had promoted.

Barth and Bultmann both shaped Jenson's theology in profound ways. Jenson was a lifelong admirer of Bultmann and was initially fascinated with his eschatology. Bultmann said that the future is opened to us by a word-event of God, a creative, history-forming, reality-shaping utterance that breaks into our world and enables us to live for the future. Jenson would consider the gospel as just this type of utterance. It is a promise spoken that guarantees a new future for the one who responds in faith. ${ }^{10}$ And yet, Jenson felt that Bultmann's account of the future did not have anything inherently christological about it. Eschatology for Bultmann appeared qualitatively opposed to history, meaning that the concrete acts of Jesus could not be eschatological - and therefore not theological knowledge, on Bultmann's account. ${ }^{11}$ Furthermore, it seemed to Jenson that Bultmann's Christ continued to possess only a functional significance. Chalcedonian statements about the full deity and humanity of Christ cannot be taken as ontological descriptors of Jesus. They merely point to the fact that God's eschatological salvation has been enacted in the death and resurrection of Christ, without any necessary connection to Jesus' history. It was the sheer "thatness" (dass) of Jesus' existence that was the occasion for the kerygma. ${ }^{12}$ Jenson found this problematic. If the eschaton did not have any realistic content to say about God, then God in the end remains unidentified in revelation. Jesus Christ, in Jenson's estimation, had to contain some ontological descriptive power for the being of God, or else God could not be spoken of in creaturely terms. Or worse, in the lack

9. Kay, Christus Praesens: A Reconsideration of Rudolf Bultmann's Christology, 16-17.

10. The gospel, Jenson claimed, was "the story of Jesus, told as a promise." Robert W. Jenson, "A Theological Autobiography, to Date," Dialog 46, no. 1 (Spring 2007): 48.

11. Robert W. Jenson, Systematic Theology (New York: Oxford University Press, 1997-1999), 1:169.

12. Rudolf Bultmann, "The Concept of the Word of God in the New Testament," in Faith and Understanding (London: S.C.M., 1969), 310-11. 
of specificity, one could fill the name "Jesus Christ" with whatever culturally inherited content that one had available. $^{13}$

Barth provided an answer for Jenson's concerns. He had lost the original eschatological emphasis, Jenson thought, but, in its place, Barth gained the content of the gospel proclamation: the presence and activity of God in Jesus Christ as the Word made flesh. Barth forged an ontological identity between Jesus Christ's historical particularity and God's inner life through a renewed interest in the trinitarian and Christological dogmas of the church. Through the study of Barth's doctrine of election, Jenson learned that God's own eternal history, lived in the mutuality of Father, Son, and Spirit, is the history of God with humanity in Jesus Christ, where God and humanity exist within a shared sphere of history. ${ }^{14}$ Jesus' history is itself the event of God's triune life, the very enactment of God's being in history. Barth united the event of Christ with the history of Jesus of Nazareth, so that there was no going behind this human life to find God. Barth, Jenson says, presents us with the most complete and compelling metaphysical system since the collapse of Hegelianism, with the Church Dogmatics as "an enormous attempt to interpret all reality by the fact of Christ." 15 Jenson's task throughout his career was to continue this fundamental insight of Barth's and to translate it into the North American context.

From here, we can summarize Jenson's Trinitarian metaphysics as follows. A trinitarian metaphysics, according to Jenson, begins first on the assumption that God is revealed fully and comprehensively in the history that God lives with Israel, brought to completion in Jesus Christ. ${ }^{16}$ This metaphysics holds the Creator-creature distinction as a fundamental postulate of Christian theology, offered to us concretely in the person of Jesus Christ, who is both true God and true humanity. But core to the Creator-creature distinction is that we do not express this relation by way of oppositional pairings - whether by paradoxes of time and eternity, eschatology and history, creation and reconciliation, and so on. ${ }^{17}$ Jenson does not deny the freedom of God over against history, but simply resists establishing this freedom by means of oppositional relationships. According to Jenson, if Jesus Christ is (in the fully ontological sense of the Word) God, then God's being must not be opposed to time or separate from it. God must instead possess an intrinsic compatibility with time.

God is identified positively for our perception because God's being is identified both by and with his history with Israel - a history that culminates in the person of Jesus Christ. ${ }^{18}$ Here is Jenson's narrative

13. Jenson feared that this is what had happened in the American context. Robert W. Jenson, "About Dialog, and the Church, and Some Bits of the Theological Biography of Robert W Jenson,” Dialog 11, no. 1 (Winter 1972): 39.

14. His earliest argument in this vein occurs in his doctoral dissertation, published as Robert W. Jenson, Alpha and Omega: A Study in the Theology of Karl Barth (New York: T. Nelson, 1963). His interpretation of Barth was textured by the influence of his doktorvater, Peter Brunner, who made a similar claim. Robert W. Jenson, "The Doxological Concept of History in the Theology of Peter Brunner," in Zur Auferbauung Des Leibes Christi: Festgabe FüR Professor D. Peter Brunner Zum 65. Geburtstag Am 25. April 1965, ed. Edmund Schlink, Peter Brunner, and Albrecht Peters (Kassel: Stauda, 1965).

15. Jenson, Jenson, Systematic Theology, 1:21. The relation of Jenson's work with Hegelianism is complex, in part because of the ways Hegel himself has been interpreted. David O. Bruner, "Jenson, Hegel and the Spirit of Recognition," International Journal of Systematic Theology 21, no. 3 (2019): 314-335. Jenson is clear that he could accept Hegel only if interpreted along right-Hegelian lines. He rejected left-Hegelianism's claim that the finite is left behind after the infinite's sublation of the form, arguing instead that the infinite always exists together with the finite, never casing off the temporal form. In the end, however, what moved Jenson in this direction was his Christological commitment to identifying the Word fully with Jesus of Nazareth, something that was owing originally to his Lutheran sympathies, rather than to any underlying commitment to Hegel. Robert W. Jenson, "What Kind of God Can Make a Covenant? (2012)," in The Triune Story: Collected Essays on Scripture, ed. Brad East (New York: Oxford University Press, 2019), 310; Stephen Wright, Dogmatic Aesthetics: A Theology of Beauty in Dialogue with Robert W. Jenson (Minneapolis: Fortress, 2014), 111-17.

16. Jenson, Systematic Theology, 1:163.

17. Robert W. Jenson, “Creator and Creature,” International Journal of Systematic Theology 4, no. 2 (2002): $216-221$. 18. Jenson, Systematic Theology, 1:63. 
theology. God chooses to be perceived by creatures by identifying with contingent historical events. That God is revealed by a particular historical reality is in itself not revolutionary; even the Ritschlians could admit as much. God must not only be identified by the event, but also with the event of his revelation. If God were merely revealed by an event, it could be that a hidden God would masquerade under these historical actions, by no means ensuring a knowledge of the God behind the event. ${ }^{19}$ God must be identified also with the events of revelation in Israel and her Messiah, such that these historical events occur within the eternal history of God. The historical event of Jesus Christ is redemptive and revelatory because God chooses to identify himself fully by and with Jesus of Nazareth.

Through God's revelation as Father, Son, and Holy Spirit, God is revealed as temporal infinity. Because God is triune, God is not opposed to time, but contains a time and a history that is appropriate to God. ${ }^{20}$ The Father as the arche is the God of the past, the God of creation. However, the Father is not a prisoner of the past, for God is a lively God, the Living God of Abraham, Isaac, and Jacob. The liveliness of God is the God of the future - that is, God the Holy Spirit. The Spirit is the future of God that sets the being of the Father free from a static past existence. Between the two, there is an identity of the Father and the Spirit through Jesus Christ, who is God the Son, the Word made flesh. The Son is the reconciliation of God's past with God's future, bringing all the polarities of God's unique temporal existence into a dramatic unity. Jesus Christ, however, is not merely God the Son, but the Son in union with Jesus of Nazareth. And as the unity of God with humanity, Jesus Christ is not only the Son with his human nature, but the Son together with the people who are united to him by faith. The place in God for creation is Jesus' humanity. Creation exists in God, therefore, not in a pantheistic fashion, but because of the divine-human unity in Jesus Christ, in which God the Son is united to his people the church by his death and resurrection. The church exists as the people whom Christ has reconciled to himself, united in his one person as the totus Christus, which will be perfected eschatologically.

By union with the Son, the church - and in the end, according to Jenson, all of created reality - is deified, brought perfectly into the divine conversation of Father, Son, and Holy Spirit. Thus, creation's goal is to be caught up in the triune discourse, which is not abstract. The conversation of the triune God is the gospel: the history of God with Israel, brought to its fullness in Jesus Christ. The goal of creation is to be caught up in the story of the gospel, and the telos of each person's life to find their own stories included in the story of Jesus Christ. To use Jenson's musical metaphor, God is a great fugue, and creation consists as a myriad of variations on a theme: the theme of Jesus Christ, who exists in the Father, through the Spirit. ${ }^{21}$

\section{Trinitarian Metaphysics as a Critical Theology of Culture}

In a 2005 festschrift for Stanley Hauerwas, Jenson addressed a topic that, upon first glance, appears fundamentally opposed to the needs of theology in a post-Christendom world (and not to mention Hauerwas's theology itself!) This essay, entitled, "Christian Civilization," explores the question of Christian culture and its relation to the church. Jenson's attitude towards the collapse of Christendom is one of both appreciation and critique. On the one hand, he says, "There are those who regard "the Constantinian settlement' as a fall of the church, and Christendom as an exile." 22 He could not agree fully with this assess-

19. Jenson, Systematic Theology, 1:59.

20. Jenson, Systematic Theology, 1:216-18.

21. Jenson, Systematic Theology, 1:236.

22. Robert W. Jenson, "Christian Civilization," in God, Truth, and Witness: Engaging Stanley Hauerwas, ed. L. Gregory Jones, Reinhard Hütter, and C. Rosalee Velloso da Silva (Grand Rapids: Brazos Press, 2005), 155. 
ment, admiring as he did the treasures that Christendom brought to the church. He explains, for example, that "I, like every other alumnus of the liturgical movement, take the fourth-century liturgies as normative." Furthermore, in view of the endless perpetuation of church divisions, he would take refuge in the ecumenical councils of the early church. ${ }^{23}$ So Christendom was not a total loss. On the other hand, as much as he admired some aspects of the Christian past, Jenson remarked that in "contemplating the dismantling of Christendom that has occupied my whole life, I wish God would hurry up." 24 Clearly then, Jenson's understanding of Christian civilization was not simply a nostalgic and uncritical acceptance of the Christian past. There is a deeper dynamic in Jenson waiting to be unearthed.

If we take this essay as a thought experiment in trinitarian metaphysics, we can see how his theology of culture contained the seeds for self-reflection upon Christian culture. His account begins with a foundational premise: the church itself as a culture. That is, the church is "a group of deliberate human practices and artifacts that mutually and independently of the momentary intents of their users make a functioning system of signs." 25 Defined as such, the church everywhere and at all times is a culture. Furthermore, if the church is in fact a culture, then it could also become a "high culture." In a high culture, distinctive cultural practices are cultivated, "not only in their communal functions but also for their own value." ${ }^{26}$ High cultures operate using a system of signs for the community, as does every culture. However, the system comes to incorporate more complex semantic and syntactical structures over time, so that the purpose of the sign becomes less a matter of pragmatics and more of aesthetics. This type of culture is precisely what developed in the Christian West. The poetry of Prudentius, for example, was poetry for its own sake, rather than for use in the liturgy. Church buildings are another example - and a fascinating one, given disputes among some Christians regarding the need for expensive and lavish buildings. Functionally, Jenson says, "church buildings are there to keep the rain off of the liturgy." ${ }^{27}$ But as Christian high culture developed in the West, the buildings became important for their own sakes. Architecture became more ornate, and people began to incorporate symbolism drawn from the church's worship into the design of buildings.

Finally, what does Jenson mean by the conflicted term: Christian "civilization"? A civilization is what happens when a high culture is adopted by the dominant class in a given society. As the history of European culture would have it, Jenson says, Christian civilization occurred when the Barbarians sieged Rome and pillaged the splendors of the newly Christian empire. Care must be taken at this point, however, for it is important to clarify what Jenson means by a "Christian civilization." Some might be tempted here to think that he conflates the church's high culture with Western civilization, but it is crucial to keep his terms straight. Cultures are not civilizations, according to Jenson. Civilizations have cultures, but they are not themselves a culture. By distinguishing between culture and civilization, with the church occupying only one side of the equation, Jenson makes a strong distinction between the church and civilization, the church and the world. The church's high culture in Europe was plundered to form a civilization, but the church's high culture is not strictly identical with the resulting civilization. Here is where Jenson appears most in line with Hauerwas. Though the Constantinian West blurred this distinction by making the church's

23. Jenson, "Christian Civilization," 155.

24. Jenson, "Christian Civilization," 155.

25. Jenson, "Christian Civilization," 155.

26. Jenson, "Christian Civilization," 155.

27. Jenson, "Christian Civilization," 156. 
high culture the basis of civilization, the church and the world were and are always separate. The church, Jenson emphatically asserts, is not and never will be a civilization. ${ }^{28}$

How then does Jenson explain the rise of Christendom? The first thing to say is that it was not a necessary development. Nothing is mandatory about creating a Christian civilization. The church does have a stake however in high forms of its culture, regardless of its social situation. Here we see how trinitarian metaphysics forms a theology of culture. According to Jenson, the church is encouraged to develop higher forms of its culture because it emulates the high culture of the triune God. He explores this by further identifying three definitions of "culture." ${ }^{\prime 29}$ First, a culture is a group's mutual behaviour that is maintained primarily by teaching, rather than by genes or physical ecology. It is a set of behaviours that are maintained by a generational tradition of communication. Secondly, a culture is the group's mutual behaviour in their system of signs, abstracted from the persons performing the behaviours. In other words, culture is the process of transmitting one's system of signs, but it is also the semantic system itself. And finally, culture is what a group does with the nature and surrounding creation that are presented to them. Culture is therefore the transmission of a system of signs through teaching, the semantic system, and the use this community makes of the world the people inhabit. High culture is the intensification of these qualities for their own sakes. The church, Jenson says, is a culture in all three senses of the word. As symbols become increasingly complex, teaching is required as it makes significantly more time for new members to be initiated into the community. And as the community inhabits their world, the natural world around the culture is increasingly transformed by the practices of the community.

But so far, Jenson has been speaking of the church's culture, of course leading one to wonder: what is the culture of the church? The church has had as many cultural expressions as it has geographical and ethnic locations, reflecting the wide variety of people to whom the gospel has spoken. How then can Jenson speak of a single church culture? This is possible, Jenson argues, because the culture of the church is not identical with a particular human expression. The culture of the church is the triune God, a community that is itself the perfect high culture. He can speak of the culture of the church in the singular because the church's culture is not any given church in the world, but the culture of the Trinity, to which the church in all times and places aspires to emulate. From here, Jenson returns to his three marks of a culture. ${ }^{30}$ The Trinity is a perfect culture not simply because it transforms nature, but because it is the triune God who establishes nature in the beginning. The triune persons are also a perfect system of signs, insofar as each person refers to the others in their mutual, personal relations - the Father speaks the Son, the Son referring back to the Father, and the effect of their speech being the Holy Spirit. The triune persons are constantly in the process of speaking this culture to one another, as the Father, Son, and Spirit speak to one another. And the character and content of this triune culture is the narrative of Jesus Christ, such that the particularity of Jesus Christ - born of Mary, living in Palestine, eating and drinking with sinners - has significance for all people and all cultures. His existence does not merely reveal the culture of the Trinity, but is the very enactment of the life and culture of the Trinity in our midst.

28. Jenson drew a distinction between the church and the world which, even when blurred, remains intact. Even if the surrounding culture is identical with that of the church, there is no collapse of the church-world distinction. He goes on to say that "the church is not herself a civilization, because she is a polity, and a civilization is not. The church is the segment for this age of the single and unitary city of God, whereas a civilization may encompass dozens of polities or none at all." Jenson, "Christian Civilization," 162.

29. Jenson, "Christian Civilization," 158.

30. Jenson, "Christian Civilization," 160-61. 
For Jenson, therefore, it is clearly the goal of all creation - and thus for human cultures - to become incorporated into the culture of the triune God through deification. ${ }^{31}$ The narrative of Jesus Christ possesses universal significance for all people because Christ unites himself with all human creatures, drawing them into his relationship with the Father and the Spirit. By identifying the history of Jesus Christ with the history of the triune God, Jenson extends the particularity of Jesus' human life to encompass all of creaturely reality. The culture of Jesus of Nazareth - his story, the signs and semantics of his story, his ordering of creation - is the culture to which we must conform. But it is important to remember here that the fulfillment of this incorporation happens eschatologically. Jesus Christ is the presence of the eschaton here and now, and so has drawn the church into the high culture of the triune God. But the full incorporation of the church into the culture of the triune God will only be completed eschatologically. Here is the critical element of Jenson's trinitarian metaphysics as a theology of culture, for because the full deification of the people of God lies in the future, no human culture can today claim to be identical with the triune community. No church, culture, or civilization can therefore truly be considered a Christian civilization. The church will be a Christian civilization only when God is all in all.

Jenson's teaching on deification raises a question, however, concerning the freedom and diversity of creation. It would appear that if God is all in all, then the creature is nothing. ${ }^{32}$ The question is whether God can truly incorporate other beings into the triune life while maintaining genuine creaturely difference, between creatures and God, as well as internally between creatures. Is human cultural diversity possible in a soteriology of deification? This is an important question that will be addressed in the second half of this essay, but to state it briefly at this point, Jenson's answer is that God incorporate creatures into the triune life by deification because God is compatible with time. If God were oppositionally related to creation that is, if the extension of either divine or creaturely agencies meant an intrusion upon the agency of the other, setting the two in ontological conflict with one another - then deification would entail a monistic absorption of creation into God, since the existence of the world alongside of God necessarily trespasses on the divine agency. But if God and creation do not exist together in this way, if God and creation are not two "things" that jostle over agency, then creation can exist in and with God by grace without annulling creaturely difference. To be sure, there are moments in Jenson where this difference appears ambiguous. Particularly in his dialectical identification between Christ and the church, some worry that Jenson does not give adequate voice to the distinction between the two, something to which he certainly could have given more consideration. ${ }^{33}$ However, while the danger cited here is certainly a risk for Jenson, his emphasis on

31. Jenson, Systematic Theology, 2:311.

32. Similar to Erich Przywara's contention against Karl Barth in the course of their discussions of the analogia entis. He claimed that Barth's theology was a style of "theopanism," in which the creature becomes but a manifestation of God's will, with the result that God becomes everything at the expense of the creature. On the opposite pole is a pantheism that makes God everything by erasing the Creator-creature distinction. Commentators on Jenson have perceived both of these tendencies. Erich Przywara, Analogia Entis: Metaphysics: Original Structure and Universal Rhythm, trans. John R. Betz and David Bentley Hart (Grand Rapids, MI: Eerdmans, 2014), 165-67.

33. Though Jenson is not alone in his dialectical identification of Christ and the church (Barth does the same the ecclesiology of $C D$ IV, to a different effect), some have worried that he does not draw a strong enough distinction between Christ and the church, resulting in the church appearing beyond scrutiny. See Brad East, "The Church and the Spirit in Robert Jenson's Theology of Scripture," Pro Ecclesia 28, no. 3 (2019): 278-300; Susan K. Wood, "Robert Jenson's Ecclesiology from a Roman Catholic Perspective," in Trinity, Time, and Church: A Response to the Theology of Robert W. Jenson, ed. Colin E. Gunton (Grand Rapids: Eerdmans, 2000), 178-87. Presently, the church is dialectically identical with Christ: identical with Christ, but only insofar as Christ stands over against the church as an other. In the future, however, this dialectic will end and Christ will be perfectly available in his community. Jenson, Systematic Theology, 2:341-42. He does attempt to draw a distinction between Christ and the eschatological church, though many have found it unconvincing. 
the basic compatibility of God and creation (something that has found considerable favour in modern theology) means that it is possible for creation to be deified without becoming God. ${ }^{34}$

Moreover, as we will see shortly, not only does this non-oppositional relation prevent a final collapse of creaturely difference from God, but it also makes possible an affirmation of creation's intrinsic value and goodness. Jenson's metaphysics affirms the freedom and goodness of all things, for even in a deified state, created reality is incorporated into the being of God exactly as what it is: the good product of God's self-donating gift of being, that which is genuinely other than God but nevertheless loved by God in Christ. Because God and time are not in conflictual relation, the envelopment of all things by God does not mean a diminishment of creaturely freedom or the loss of creaturely integrity. Creation can participate in the triune life without at all ceasing to be itself, since the extension of God's agency into the realm of creaturely agency does not involve a diminution of anything that is made. Because theological compatibilism enables deification without erasure of difference, the integrity of created being remains intact. Jenson could therefore affirm, just as the Catholic tradition would before him, that "grace does not destroy, but perfects nature." 35

The church is a culture, and because the church exists within the life of God, it has a reason to cultivate this culture and form it into a high culture, reflecting the high culture of the Father, Son, and Holy Spirit. But the culture that the church seeks to emulate is not to be equated with any humanly available cultural form. To collapse any present human culture fully into the trinitarian culture of God would be to erase the Creator-creature distinction. Instead, Jenson's trinitarian metaphysics contain first a critical element, excluding from the outset any idea that any one human culture could become ultimate or superior. Cultural captivity of Protestant churches to contemporary late modern individualism and capitalism was in fact his greatest fear, so that in a sense, his trinitarian metaphysics was a means of preventing the collapse of Christianity into Western culture. The church's destiny is perfect incorporation into the triune culture. Until that time, the church is not able to claim any one of its own cultural expressions as the single faithful expression of this high culture. It means that we must always be revisionary, always reflective upon the extent to which our cultural forms and structures are faithful to the gospel, the culture to which we must all aspire. And as Jenson modeled in his own writings, self-reflection begins with one's own household. ${ }^{36}$

Thus, although Christian civilizations are not necessary, the church is always a culture, and therefore has a stake in high forms of its culture. This type of culture existed and continues to exist in West-

34. Many other contemporary scholars have noted the importance of this non-oppositional relation, who otherwise stand at a difference from Jenson on a number of other topics. See, for example, Karen Kilby, God, Evil and the Limits of Theology, 1st ed. (New York: T\&T Clark, 2020); Katherine Sonderegger, Systematic Theology, Volume 1: The Doctrine of God (Minneapolis: Fortress, 2015); Kathryn Tanner, God and Creation in Christian Theology: Tyranny or Empowerment (Oxford: Blackwell, 1988); Rowan Williams, Christ the Heart of Creation (London: Bloomsbury, 2018).

35. Jenson, Systematic Theology, 2:65-68; cf. Robert W. Jenson, "Gratia Non Tollit Naturam Sed Perficit," Pro Ecclesia 25, no. 1 (Winter 2016): 44-52.

36. It is an undoubtedly important question how Jenson's theology works interculturally, something that will be the task of theologians other than the present author, who inhabits the same cultural space as did Jenson. But it is important to know what Jenson was concerned about. He wished to guard against a cultural imprisonment of Christianity to late modern American culture, a conflation of the gospel to the forms of contemporary North American society. Thus, though some might be uncomfortable with his opposition to concepts of inculturation or contextualization, it is important to remember what Jenson was against. He was not entirely against the idea of inculturation. It was simply unavoidable that the gospel would take particular historical and temporal forms unique to the cultures in which it lives. Jenson, Systematic Theology, 1:9. Jenson resisted rather any systematic emphasis on inculturation or contextualization, but this was not out of any fear of what Christians might do in other cultures. His concern rather was that it would justify the Americanization of the gospel for the purposes of Western culture. He was no nationalist, and wanted to maintain the ability to be critical of his own society. Green, The End Is Music: A Companion to Robert W. Jenson's Theology, 11. 
ern Christendom, but it is not restricted to the West as such. Jenson acknowledges the possibility that the church has created and will create high forms of its culture among various people groups. Christian high culture does not have Western Christendom as its minimum standard, for the high culture that the church seeks to emulate in all times and places is the high culture of the triune God. All cultures will fall short of the ideal, but the church in all places participates in it. Therefore, we must beware of equating one human culture with God's triune life. Not only may this lead to sentiments of cultural superiority and nationalism, but it also violates the central feature of Christian theology: that there exists a fundamental distinction between God and creation, and that God is given to us only in Jesus Christ, who is not the Lord only of one culture, but of all who call upon his name.

\section{Trinitarian Metaphysics and the Theology of Culture}

To be consistent with Jenson's method, we cannot stop here. So far, we have spoken in a negative or apophatic mode, explaining how his metaphysics challenges our inherited culture by calling the church to imitate the culture of the triune God, which is only imperfectly mirrored the present. The church participates in the culture of the triune God while the church awaits its full transformation in the future. But Jenson did not believe a critical theology to be immune to distortion from one's own biases. Negative statements about God can become the occasion of harmful cultural impositions, just as much as positive statements. Theology functions best when apophatic and cataphatic statements about God are held together in tension. Therefore, we must now speak cataphatically. Jenson's metaphysics contain the seeds for a constructive theology of culture, allowing the church in all times and places to cultivate her culture in ways that are both faithful to a peoples' own historical particularity, as well as to the continuity of the church as Christ's one body.

At the end of the festschrift essay, Jenson describes the warrant of a Christian civilization. It certainly was possible for the church to create a Christian civilization, but was this a good thing to do? Jenson replies that Christendom happened by a somewhat inevitable historical occurrence, what he elsewhere calls a "dramatic necessity" or a "contingent necessity." 37 According to Jenson, when certain events happen in history, they become contingently necessary: contingent because things did not have to happen that way, but necessary because, having happened, the events become an intrinsic part of the story. Any number of things could have happened, but in retrospect, things simply had to happen the way they did. And because they did in fact happen, we cannot simply disregard them. ${ }^{38}$ The developments take on a necessity of their own, so that the practices, language, ideas, and theology developed in the past cannot be discarded without denying the presence of the Spirit to the church at that time. Human beings are traditioned creatures - storied beings - and so need to maintain continuity with the past, even as they are open to the future.

History would have it that the church's high culture in Europe became a Christian civilization, something many deride as a corruption of the Christian message. Jenson certainly believed it possible for the church to have her cultural treasures despoiled by the surrounding world. But this is a risk the church had to take. As the church lives and moves in the world, it must be open to sharing its culture with the nations. "At that point," Jenson says, we must "turn the risk management over to God." 39 The church must share its cultural treasures with the nations, for it anticipates a future in which the whole of creation partici-

37. Jenson, “Christian Civilization," 157; Jenson, Systematic Theology, 2:240.

38. A concept that Jenson holds in common with Lindbeck. See Lindbeck, The Church in a Postliberal Age, 160-165.

39. Jenson, "Christian Civilization," 163. 
pates in the same loving fellowship with the triune God that the church experiences in the present. Therefore, the church must risk its culture in openness to the world, recognizing that the Word of God speaks and resounds outside of the church's borders. ${ }^{40}$ The universality of the gospel means that the church cannot withdraw from the world, for God speaks the world into existence and the entirety of creation that is destined to become enmeshed within the culture of the triune God.

How then does Jenson make room for free human cultural development? He does so through his "roomy" doctrine of God. As Rowan Williams has argued in his recent book, Christ the Heart of Creation (2018), the integrity and freedom of creaturely agency can exist only where divine and human agencies are not in competition with one another. When God is considered as simply another finite agency, intensified to the highest degree, the result is that God and creation are set into an oppositional, zero-sum relation: a tug-of-war where the actions of God necessarily exclude human actions, and vice-versa. ${ }^{41}$ And as the final chapter of Williams' book argues, this ontology trickles down into the societal and political spheres of human life. But the infinity of the triune God is much more radical than an oppositional relation would imply. It is not in contradiction to, but precisely on account of God's infinite and qualitative otherness from creation God cannot relate to creation in an oppositional manner. The infinity of God's being is expressed precisely in that God is not in competition with the creature, but rather opens the creature to its infinite ground in the triune life. On this basis, human beings are freed for self-sacrificial action and solidarity with creaturely others.

Jenson's metaphysics propose a similar vision. ${ }^{42}$ God does not exist in opposition to the creature but is compatible with time. In Jenson's own terminology, God is “temporally infinite": "The biblical God's eternity is his temporal infinity. Any eternity is some transcendence of temporal limits, but the biblical God's eternity is not the simple contradiction of time. What he transcends is not the having of beginnings and goals and reconciliations, but any personal limitation in having them [...] The true God is not eternal because he lacks time, but because he takes time." ${ }^{\prime 4}$ God is God, not because God lacks boundaries, but because he overcomes and exceeds all boundaries. ${ }^{44}$ This does not lead Jenson to erase the Creator-creature distinction, as some would fear. What he rejects is any description of the contrast between God and creation that operates by oppositional pairings (e.g., time-eternity, transcendence-immanence, finite-infinite). God's qualitative difference from creation cannot be understood along the lines of an oppositional relationship, but must be understood through God's essential compatibility with time. ${ }^{45}$

This metaphysics of non-competitive relation contains implications not only for God, but for creation also. If God is all in all, then part of the task of Christian metaphysics is explaining the possibility of creaturely freedom as an object distinct from God. And for Jenson, God's temporal infinity means creatures are free to be themselves, because "God is roomy." That is to say, "God can indeed, if he chooses,

40. What is normally known as common grace, general revelation, or Barth's "little lights." Jenson, "Christian Civilization," 163.

41. Williams, Christ the Heart of Creation, 11.

42. The non-oppositional relation is consistent with postliberal theology. The idea that finite and infinite agencies are not in competition was the main argument of Austin Farrer's book, The Finite and the Infinite (Westminster: Dacre Press, 1943). See Williams, Christ the Heart of Creation. Hans Frei was not in favour of so formal a metaphysical project as Jenson's, borne out of a desire to avoid the over systematization of theology. Frei did, however, appreciate Farrer's metaphysics (once again, used in ad hoc fashion).

43. Jenson, Systematic Theology, 1:217.

44. Jenson, Systematic Theology, 1:216.

45. As Jenson saw it, the distinction of Creator and creature is too often laid out conceptually according to metaphysical distance. He preferred to establish it through narrative (i.e., the narrative of Jesus Christ, revealing God's transcendence and immanence of the creature in Christ's one person). Jenson, "Creator and Creature," 216. 
accommodate other persons in his life without distorting that life [...] He can, if he chooses, distinguish himself from others not by excluding them but by including them." ${ }^{46}$ God does this most prominently in Jesus Christ, who as the Son fully inhabits the life of the triune God and lives a genuine human life, united together in a single hypostasis. In the life of Jesus, we are granted a window to perceive the difference of God and the creature. But in perceiving the difference of God and creation, we also see them unified in this first century Jewish man, born of Mary, crucified under Pontius Pilate. The Son, in his union with humanity, makes room for creation within the life of God: "God as Father, Son, and Spirit can make room in himself for others, and the room that he makes is our created time. The opening of that room is the act of creation." 47 This creation is not a static object, but a history, a story: "God makes narrative room in his triune life for others than himself [...] we are within the divine life as participants. ${ }^{48}$ Thus, creation is fully itself, without diminishing God in the process, because God accommodates other beings within the triune life through Jesus Christ.

Because God remains distinct from creation even as he grants them a share in his divine nature, creatures are in turn free to be who they are. Furthermore, human beings in particular are free for cultural development, affirming the goodness in the diversity of human cultural expression. To see how Jenson's metaphysics might enable cultural development, we may look to chapter twenty-one of his Systematic Theology, in a section entitled, "The Other Creatures." As we have seen, part of Jenson's understanding of "culture" is the development of the natural world. As such, we are not just dealing with the free agency of human beings, but also human relation to non-human creation. Jenson already established in a previous chapter that human freedom is derivative from humanity's creation and participation in the triune life. Drawing on Martin Luther, Jenson says that human beings do not have a liberum arbitrium; only God has a truly free will. Human beings are free because they are "rapt" or caught up into the freedom of the triune God through Jesus Christ. The creaturely freedom guaranteed by the biblical God extends also to nonhuman creation. The other creatures are free in the life of God because they are not God. Christianity "secularizes" the cosmos by making it abundantly clear that creation is not God, which enables creatures to be authentically what they are: a good creation, brought into being by and for God. The Creator-creature distinction means that the things of the earth are not God - and this is no insult. It means that creation is free to be what it is.

The freedom of creation opens human beings to cultural development. Human beings are given "dominion" over the creation, but this is no tyrannical overlordship: "we are gardeners of someone else's garden." ${ }^{\text {"49 }}$ Human beings are to exercise a similar governance over the creation as does God, not built on brute power or manipulative control, but a rule that brings about the flourishing of all creatures. We are free to develop creation, free to form culture - and the possibilities are endless. Non-human creation participates in the life of the triune God, as an object of his affection and enjoyment. Creation therefore is an inexhaustible mystery, to be delighted in with a joy that is inexhaustible. ${ }^{50}$ Our enjoyment of creation is li-

46. Jenson, Systematic Theology, 1:226.

47. Jenson, Systematic Theology, 1:226.

48. Jenson, Systematic Theology, 2:34.

49. Jenson, Systematic Theology, 2:115.

50. This confession of creation's goodness finds a necessary challenge in the presence of evil in the world, raising the question of theodicy. Creation is not always delighted in; it is often cruelly indifferent to the sufferings of its inhabitants. Jenson is clear that he presents no theodicy, believing as he did that most proposed solutions to the question of creation's goodness and the presence of suffering inevitably justify evil (moral and natural) as an intrinsic good. In his words, it is the only reasonable objection to the existence of God, and he long resisted the temptation to use God as a bulwark against the chaos of historical existence. The best one might do, he thought, is inhabit the death and resurrection of Christ, which provides for us both the goodness of creation as well as the suffering and evil brought to its pinnacle on Christ's cross. But 
mitless, not because creation itself is limitless, but because the limit of creation is nothing less than the future of God the Holy Spirit: "The world is indefinitely complicated because it is counterpart to the internal perichoresis of the infinite God." ${ }^{51}$ Human beings may therefore delight in other creatures as God delights in creation: "What we may do about Pleiades and Orion is have fun with them, even from our distance." 52 Jenson's metaphysics therefore turn towards a blossoming of non-human creation, and with it the infinite possibilities of human cultural development. The possible paths of human culture are as endless as God is infinite. Christians from all around the world can therefore inhabit the story in their own unique cultural contexts, bringing forth a wide variety of cultural expressions, because this is the freedom of the creation as it exists in the life of Father, Son, and Spirit.

But do we therefore abandon the postliberal interest in the narrative particularity of the church and her Scriptures? The answer is no. Creation's existence within the Trinity is not a natural capacity, not something that creatures possess by their own right. The whole cosmos enters into communion with the Trinity because one of the Trinity became a human being - Jesus Christ, born of Mary, who walked the first century world, who was crucified and risen in our space and time. The mystery of Jesus Christ is that his particularity gives rise to the universal telos of creation. Thus, all cultures must become the culture of this man, for the culture of Jesus Christ is the triune God. One must not therefore become a Western European or North American Christian. Contemporary Eurocentric civilization possesses no more right over the culture that is Jesus of Nazareth than does any other culture. Furthermore, it is not necessary for cultures to abandon all their inherited forms and structures of life (though in some cases, e.g., with Western consumerism and individualism, it is necessary). Because God and time do not relate in opposition to one another, a person does not need to abandon their resident culture in order to inhabit the culture of Jesus Christ. The Spirit's working in the church means that God will continue to take up the tangible structures of the church's life and use them to incorporate the people of God into the triune community through union with the Son.

This does not solve all of the practical questions, and one might wish that Jenson could have provided more in the way of specifics. ${ }^{53}$ How do we understand the binding nature of historic dogmas in relation to the autonomy of local churches, embedded within diverse cultures? Can Christians in one culture make prescriptive judgments about the moral shape of the church's life in another culture? What of the liturgical life of the local churches and their continuity with the historic practices of the church? How do we discern whether a culture must remain as it is, or must shed some of its inherited characteristics to be faithful to the gospel? Jenson does not answer these questions, for they are not his to answer. On the one hand, we must not deny the agency of the Spirit at work in the church historically by abandoning the church's historic practices and forms of life. On the other hand, it is the church in those times and places

one must not allow the sufferings of the present to circumscribe the intrinsic goodness of the world. Jenson, Systematic Theology, 2:21-24.

51. Jenson, Systematic Theology, 2:129.

52. Jenson, Systematic Theology, 2:130.

53. Even sympathetic readers like Stephen John Wright feel as though Jenson gave contextual theologies such as feminist theology a poor treatment, even if he had his reservations. Wright certainly has an important point to make here. As discussed earlier, Jenson was always aware that theology was contextual, and he even made use of some of the theory behind contextual theology in his book on the biblical canon. Robert W. Jenson, Canon and Creed (Louisville: Westminster John Knox, 2010). Further, what concerned Jenson was that contextual theologies tended to stop with apophatic negation of our words and often provided lacklustre constructive solutions. Noting his concerns, however, it is possible that contextual theology could play a larger role in his revisionary theology, even if one does need to note the limitations. As Wright notes, Jenson's opposition to these theologies mask similarities that could result in fruitful dialogue between them. Stephen John Wright, "Sounding out the Gospel: Robert Jenson's Theological Project," Pro Ecclesia 28, no. 2 (2019): 164 n. 72. 

and cultures who must discern what this looks like. The church in each age and culture must reflect on how to navigate these matters faithfully. But if Jenson's metaphysics is true, then the open-endedness of these questions does not constitute a limit on what the church may say and do. It means that the future is open, constituted by the living and surprising agency of Jesus of Nazareth. Jenson was silent on how this all works, perhaps not because he ignored the problem, but because he recognized it was not the place of a European American theologian to make such pronouncements about other cultures. We may simply trust the Spirit to guide the church in the right way.

But if Jenson does not offer to answer all of our questions, his theology is nevertheless a starting point. Such matters concerning the authenticity of the church's life in a given culture and its continuity with the church of the past are not easily resolved. But Jenson's theology is a reminder that such conversations must rest first and foremost on the metaphysics of the gospel, on the premise that God is not abstracted or absent from history, but a very present actor within our story. The gospel preaches a God who is not in conflict with creation, but one intrinsically open to the created universe, compatible with creation through the person of Jesus Christ. Working out the relation of Christianity and culture will continue as long as the age, a work that is never completed. But if Jenson's metaphysics do not complete the work, he provides us with the ground rules on which the relation may be faithfully established. 


\section{Bibliography}

Bruner, David O. "Jenson, Hegel and the Spirit of Recognition." International Journal of Systematic Theology 21, no. 3 (2019): 314-35. https://doi.org/10.1111/ijst.12379

Bultmann, Rudolf. "The Concept of the Word of God in the New Testament." In Faith and Understanding, translated by Robert W. Funk, 286-312. London: S.C.M., 1969.

Congdon, David W. "Kerygma and Community: A Response to R. W. L. Moberly's Revisiting of Bultmann." Journal of Theological Interpretation 8, no. 1 (Spring 2014): 1-21. https://www.jstor.org/stable/26373859.

—. "The Nature of the Church in Theological Interpretation: Culture, Volk, and Mission." Journal of Theological Interpretation 11, no. 1 (Spring 2017): 101-17. https://www.jstor.org/stable/10.5325 jitheointe.11.1.0101.

East, Brad. "The Church and the Spirit in Robert Jenson's Theology of Scripture.” Pro Ecclesia 28, no. 3 (2019): 278-300. https://doi.org/10.1177/1063851219846679.

Frei, Hans W. Types of Christian Theology. Edited by George Hunsinger and William C. Placher. New Haven: Yale University Press, 1992.

Green, Chris E. W. The End Is Music: A Companion to Robert W. Jenson's Theology. Eugene: Cascade, 2018.

Jenson, Robert W. "About Dialog, and the Church, and Some Bits of the Theological Biography of Robert W. Jenson." Dialog 11, no. 1 (Winter 1972): 38-42.

. Alpha and Omega: A Study in the Theology of Karl Barth. New York: T. Nelson, 1963.

Canon and Creed. Louisville: Westminster John Knox, 2010.

. "Christian Civilization.” In God, Truth, and Witness: Engaging Stanley Hauerwas, edited by L. Gregory Jones, Reinhard Hütter and C. Rosalee Velloso da Silva, 153-63. Grand Rapids: Brazos Press, 2005.

“Creator and Creature.” International Journal of Systematic Theology 4, no. 2 (2002): 216-21. https://doi.org/10.1111/1463-1652.00082.

—. "The Doxological Concept of History in the Theology of Peter Brunner." In Zur Auferbauung Des Leibes Christi: Festgabe FüR Professor D. Peter Brunner Zum 65. Geburtstag Am 25. April 1965, edited by Edmund Schlink, Peter Brunner and Albrecht Peters, 181-98. Kassel: Stauda, 1965.

“"Gratia Non Tollit Naturam Sed Perficit.” Pro Ecclesia 25, no. 1 (Winter 2016): 44-52. https://doi.org/10.1177/106385121602500103. 
—. Systematic Theology. New York: Oxford University Press, 1997-1999.

. “A Theological Autobiography, to Date.” Dialog 46, no. 1 (Spring 2007): 46-54.

https://doi.org/10.1111/j.1540-6385.2007.00307.x.

—. "What Kind of God Can Make a Covenant? (2012)." In The Triune Story: Collected Essays on Scripture, edited by Brad East, 310-22. New York: Oxford University Press, 2019.

Kay, James F. Christus Praesens: A Reconsideration of Rudolf Bultmann's Christology. Grand Rapids: Eerdmans, 1994.

Kilby, Karen. God, Evil and the Limits of Theology. New York: T\&T Clark, 2020.

Lindbeck, George A. The Church in a Postliberal Age. Edited by James Joseph Buckley. Grand Rapids: W. B. Eerdmans, 2003.

Moberly, R. W. L. "Bible and Church, Bultmann and Augustine: A Response to David Congdon." Journal of Theological Interpretation 9, no. 1 (Spring 2015): 39-48. https://www.jstor.org/stable 126373872.

—. "The Significance of the Church for Theological Interpretation: A Response to David Congdon." Journal of Theological Interpretation 12, no. 2 (Fall 2018): 274-86. https://doi.org/10.5325 jitheointe.12.2.0274.

—. "Theological Interpretation, Presuppositions, and the Role of the Church: Bultmann and Augustine Revisitied." Journal of Theological Interpretation 6, no. 1 (Spring 2012): 1-22. https://www.jstor.org/stable/26421432.

Przywara, Erich. Analogia Entis: Metaphysics: Original Structure and Universal Rhythm. Translated by John R. Betz and David Bentley Hart. Grand Rapids: Eerdmans, 2014.

Ritschl, Albrecht. The Christian Doctrine of Justification and Reconciliation: The Positive Development of the Doctrine. Edited by Alexander Beith Macaulay and H. R. Mackintosh. Edinburgh: T. \& T. Clark, 1900. http://link.library.utoronto.ca/eir/EIRdetail.cfm?Resources_ID=1118095\&T=F

—. "Theology and Metaphysics." In Three Essays: Theology and Metaphysics, "Prolegomena" to the History of Pietism, Instruction in the Christian Religion, translated by Philip Hefner, 150-217. Philadelphia: Fortress, 1972.

Sonderegger, Katherine. Systematic Theology, Volume 1: The Doctrine of God. Minneapolis: Fortress, 2015.

Tanner, Kathryn. God and Creation in Christian Theology: Tyranny or Empowerment. Oxford: Blackwell, 1988. 
Williams, Rowan. Christ the Heart of Creation. London: Bloomsbury, 2018.

Wood, Susan K. "Robert Jenson's Ecclesiology from a Roman Catholic Perspective.” In Trinity, Time, and Church: A Response to the Theology of Robert W. Jenson, edited by Colin E. Gunton, 178-87. Grand Rapids: Eerdmans, 2000.

Wright, Stephen. Dogmatic Aesthetics: A Theology of Beauty in Dialogue with Robert W. Jenson. Minneapolis: Fortress, 2014.

Wright, Stephen John. "Sounding out the Gospel: Robert Jenson's Theological Project.” Pro Ecclesia 28, no. 2 (2019): 149-66. https://doi.org/10.1177/1063851219842403. 